\title{
Solar city, bike city, growth city: governance and energy in Davis, California
}

\author{
Benjamin Weil ${ }^{1}$ \\ University of Massachusetts, Amherst, USA
}

\begin{abstract}
The path home takes us past the best any community can offer: beautiful, well-loved, energyefficient solar houses; community vineyards, orchards, and vegetable gardens; waterconserving landscapes; children playing away from traffic; birds singing and nesting; neighbors talking to one another. Even the village dogs seem to know how good they've got it and seldom fight (Thayer 2000:xii).
\end{abstract}

After 35 years in Davis...we have decided to move to a community which is closer to what Davis was when we arrived. We rarely recognize familiar faces on the street any more. Unless we do something, the bicycle will lose to the car. The slow growth initiatives supported by voters have proven to be fruitless against the pressures of profit (Springer 1998).

\section{Introduction}

The prospect of catastrophic climate change combined with recently revived concerns about energy independence, fuel prices, and environmental destruction have brought renewed public discussion of such technologies as wind farms, solar power plants, biofuels, nuclear power, and coal gasification (this time with carbon capture as an additional consideration). Dramatic geoengineering projects, ranging from fertilizing the seas to deploying giant space-mirrors have been proposed in major science journals. There is less discussion among energy planners, futurists, and pundits of simple, inexpensive, and established technologies including bicycles, passive solar building design, and solar heating of domestic hot water. However, these technologies, if widely deployed, could have large and immediate impacts on consumption of fossil fuels for transportation, and the heating and cooling of buildings. It is becoming increasingly clear that achieving significant reductions in greenhouse gas emissions will depend on application of technologies at many levels: public utility-scale, household-scale, and personal scale, as well as involving social reorganization and behavior change (Pacala and Socolow 2004; Kunstler 2005; Brown 2006; Kutscher 2007).

The current energy crisis involves dependence on oil from unfriendly and unstable countries, pollution from the combustion of fossil fuels, ravaged landscapes from the extraction of fossil fuels, and a global ecosystem that has passed its threshold for accommodating continued economic growth. It bears an uncanny resemblance to the energy crises of the 1970s, which featured dependence on oil from the Middle East, smog and other health-threatening pollution, oil spills and contaminated beaches, and similar warnings about the limits to growth. Then, as now, there were calls for large-scale technological fixes (proposals to line the entire coast of California with nuclear power plants come to mind). Similarly, there were calls to re-organize and re-localize communities, and to engage changing behaviors and social norms to realize 'softer' technologies.

Large-scale technologies, if successfully implemented, may not require Americans to make significant changes in lifestyle, behavior, social organization, or basic technology choices. However, simpler small-scale technologies require active adoption by large numbers of people. During the energy crises of the 1970s — the florescence of many small-scale renewable technologies-there was considerable attention paid to behaviors and "energy frugality lifestyles" (Leonard-Barton 1981). Many analysts in academia and government suggested that the only way to solve the energy crisis back in the 1970s was to change social norms, practices, and expectations (e.g., De Young 1993; Mitchell and MacNulty 1981; Carlson et al. 1980).

To understand how these social-technological hybrids might actually work, it makes sense to find examples where they have been seriously attempted. During the 1970s and early 1980s there were a number of attempts to create collective action solutions to behavior change and to create social, civic, and technological infrastructures to support local sustainable energy economies. These attempts in the USA ranged from very small "communes" to broader urban and regional planning efforts. But the record of sustaining sustainable community projects was rather poor. The communes fractured and members moved on... and the planning commissions were de-funded or re-focused on other priorities. Some cities, like

\footnotetext{
1 Dr. Benjamin Weil, Extension Assistant Professor, Department of Environmental Conservation, University of Massachusetts, Amherst, MA 01003-9285, USA. Email: bweil "at" eco.umass.edu. I would like to thank Professors Daniel Press, Dan Kammen and S. Ravi Rajan for their guidance, support, and insight. Any errors or shortcomings that remain in this paper are my sole responsibility. This is the fifth paper in Rajan S.R. and Duncan C.A.M. (eds.) "Ecologies of Hope", special section of the Journal of Political Ecology 20: 70-179.
} 
Portland, Oregon saw many aspects of their early sustainable energy initiatives flourish and grow. Among these initiatives, few rivaled the City of Davis, California, which has been held up as an exemplar of solar design, smart growth, environmental consciousness, and alternative transportation. Davis provides a good example to study alternative responses to the energy crisis because of the seriousness of the protagonists and the longevity of their innovations and institutions. This article examines the Davis case with a focus on two types of renewable energy; human powered transport and solar heat. They were chosen as useful examples because the technologies in both cases are simple, well developed, applied at the individual or household level, and can have very high immediate impacts on the consumption of fossil energy and resulting greenhouse gas emissions.

This essay describes the development of these two technological systems in the City of Davis. In doing so, it discusses the initial rise, and subsequent decline in usage of both technologies. It also engages questions such as: (1) What is the role of local policy capacity, civic engagement, and social capital, in determining energy and land-use choices? (2) What does it take to make an environmentally sustainable city? (3) What conditions favor the widespread adoption of small-scale renewable energy technologies? (4) What conditions threaten the ability of communities to maintain and expand their use of these technologies? (5) What is the role of less-tangible assets, such as values, identity, and sense of community?

The next section provides context with a short description of Davis' geography and historical development. Following a brief discussion of the theoretical reasons to look at community, identity, and values in assessing the long-term successes and failures of local environmental sustainability efforts, is a description of the cases of bicycle transport and solar heating in Davis. I then discuss resonances with other cases and the translatability of lessons from the Davis cases to other locations and scales.

\section{Context}

The observation that there is "no magic bullet" solution to the energy crisis has become a cliché, but it was not always thus. In fact, until quite recently the dominant attitude among leading policy makers, pundits, and academics was to dismiss the contributions of energy conservation efforts particularly in the areas of residential energy use and in alternative transportation (Cheney 2001; Friedman 2008; IEA 1998). For the general public, one could argue that the pendulum has swung too far the other way, and public education campaigns persuade millions that unplugging cellphone chargers can make a large contribution to reducing energy use, while in fact it can make only a miniscule difference (MacKay 2008). Nonetheless, in the US, residential buildings are responsible for 22 percent of national energy consumption and of this, space conditioning and hot water account for 63 percent (EIA 2011). Transportation is the primary user for petroleum, and commuting in automobiles accounts about 71 percent of national petroleum use (28 percent of total national primary energy consumption). Clearly, how we provide heat and comfort in our houses, where we build them, and how we travel to and from them can have tremendous implications for our ability to reduce our consumption of risky, expensive, destabilizing, and polluting fossil fuels.

The conventional academic and policy response to both sectors largely focused on improving technological efficiency and increasing the energy supply. In transportation, the primacy of the personal automobile has rarely been challenged, and thus engineering and policy advocacy efforts have focused on improvements in fuel efficiency and advocacy for various drivetrains, fuels and energy storage systems (Sperling and Cannon 2007; Sperling and Lutsey 2009). In the residential building sector, policy efforts have been largely confined to marginal improvements to building codes, sporadic incentives for insulation, window and appliance upgrades, and solar hot water systems. Overall, policy advocacy and academic study has emphasized economic incentives and done little to address the cultural and normative context, or the community scale in which energy efficiency and renewable energy decisions are made.

Efficiency standards (CAFE standards, introduced in 1974 in the US) had a dramatic initial impact on automotive energy consumption per mile traveled, but declining fuel prices in the 1980s was the loophole for light trucks through which the popularity of the SUV (Sports Utility Vehicle) was driven (Bradsher 2002). The rebound effect was that improved miles per gallon enabled an increase in total miles driven, thus subverting the intent of the regulation (Greening et al. 2000; Sorrell et al. 2009). Economists have argued that an increasing tax on automotive fuel would more reliably drive consumers toward shorter commutes and more fuel efficient car models (Austin and Dinan 2005). However there seems to be little appetite for such a policy in the American political culture.

Fuels for internal combustion engines such as methanol, ethanol, biodiesel, and natural gas have, at various times, received glowing evaluations from academe and industry, and support and subsidy from government (Grafton et al. 2010; Rosenthal 2008; Rubin et al. 2008). Each has proved, with experience and further analysis, to have the potential to only marginally reduce carbon emissions and reduce reliance on fossil fuels - and in many cases may actually result in increased emissions of greenhouse gases and pollutants as well as destabilizing effects on food production and prices (Headey and Fan 2008; Trostle 2008; Von Blottnitz and Curran 2007).

Periodically, hydrogen emerges in the popular and political imagination as the fuel of the future (Gregory et al. 1973; Rifkin 2003). When energy stored in hydrogen bonds is released, whether through combustion or across the membrane of a fuel cell, the only emission is water. Hydrogen may be the most 
common element in the universe, but it is rare in its molecular form. It takes a great deal of energy to create a hydrogen fuel. Is it is an energy carrier, and not an energy source. Fuel cells are seen as a more efficient and cleaner way to power vehicles, and recently a great deal of federal money and venture capital has been invested in developing fuel cell technology. Fuel cells are simply batteries that are refilled with hydrogen rather than re-charged from the electricity grid. The fundamental problems with hydrogen fuel cells, including low energy density, the lack of a refueling and fuel production infrastructure, and the inefficiency inherent in a long chain of energy transformations, have yet to be solved (Balat 2008; McDowall and Eames 2006).

Considerably less attention has been paid to the question of reducing the need for automotive transportation overall. Investing in public transit and encouraging bicycle commuting has largely remained the province of idiosyncratic local and regional efforts. The broadest thinking about the transportation energy issue calls for an approach that emphasizes diversity of transportation modes and energy sources, where each type of transportation need is met in the most efficient and flexible way. But even here there seems to be an implicit acceptance of the inevitability of the general organization and distribution of American residential, commercial, and industrial infrastructure with its immutable implications for transportation modes, needs and options (Sperling and Cannon 2007). Urban and regional planning to create mixed-use, walk-able and bikeable communities can create a conducive environment, but without an accompanying attitudinal shift and a general re-organization of social priorities, bike paths become recreational assets and public transit busses drive around mostly empty.

At all scales, the lack of renewable energy technology adoption and deployment has troubled policy makers and scholars alike. Most point to economic theory for explanations and solutions. If environmental and social costs were internalized in energy prices, if historic and continuing perverse subsidies to the fossil fuel, nuclear, and automotive industries were properly exposed and eliminated, if consumers paid the marginal cost, rather than the average cost for electricity and natural gas... if prices told the truth, renewable energy could compete on a fair playing field and it would have significant market share (Corson 2002; Hawken et al. 1999; Myers and Kent 2001; Palmer and Burtraw 2005; Pigou 1920). Suggested policy responses include carbon taxes, tax credits, equipment purchase rebates, R\&D investment, green marketing, renewable portfolio standards, feed-in tariffs, and cap-and-trade schemes for carbon dioxide emissions (Niemeier et al. 2008; Mathews 2008; AWEA 2008; Palmer and Burtraw 2005; Geller 2003; Kammen and Margolis 2002; Goulder and Nadreau 2002; Rader and Norgaard 1996).

None of these market-correcting mechanisms, however, address the non-market aspects of the more diffuse and small-scale technologies. In order for people to support the above economically oriented policies, as well as to make energy conserving choices and renewable energy technology purchases at a scale large enough to make a cumulative difference, they must be supported by cultural values and community norms. Community governance can solve problems that appear as market and state failures, such as insufficient public goods and environmental amenities (Bowles and Gintis 2002). Where market or state governance inadequately supports aggregate individual or collective action, community governance sometimes can. Policies encouraging the widespread adoption of behaviors and technologies are generally designed to elicit private provisions of public goods. This configuration of interests-concentrated individual costs and diffuse general benefits - is among the most difficult for which to gain political support (Stone 2002). Private choices with a technological component need to be made repeatedly ("Should I take the bike or the car today?" "Should I maintain or restore this solar hot water system this year or should I just install a new standard water heater?"). Because of this, social pressure must also play a role in influencing community members to continue to make desired private choices. A study of energy use in university housing concluded, "energy use should properly be seen as governed by considerations of appropriateness or "normality" in given social settings or situations" (Hackett and Lutzenhiser 1991:464). The more engaged with their communities individuals tend to be, the greater the effect of social pressure (Veblen 2006; Putnam 2000; Granovetter 1985). Implicitly, in a social milieu that emphasizes energy consciousness, individuals will be more likely to think about the energy implications of their mundane decisions.

Some observers and appropriate technology advocates have argued that there is a reciprocal relationship between the scale of a technology and the civic engagement of its users, and the communities where the technology is employed (Winner 1992; Sclove 1995). In starkest terms, the comparison is made between nuclear power and solar power. Highly centralized, complex, and brittle nuclear power systems are not intelligible to the average citizen who must not interact with the technology except as an end-user (Perrow 1999; Sclove 1995; Lovins and Lovins 1982). Large, centralized technologies require authoritarian, centralized governance (Proops 2001; Perrow 1999; Gamson and Modigliani 1989; Lovins and Lovins 1982; Winner 1977). By contrast, some argue, distributed, small-scale technologies like solar water heaters require user interaction, depend on social acceptability and social networks for widespread adoption, and because they provide positive externalities, they are more likely to be supported by institutions accountable to the public rather than shareholders (Berman and O'Connor 1996; Sclove 1995).

In general, there is an often-unstated idea that "the pursuit of sustainability is inextricably linked to civic engagement" (Portney 2005:583). Early adopters of the sustainable cities initiatives, such as Seattle, Portland, Sacramento, and Boston, assumed that a highly participatory process would be needed to convince 
local elected and agency officials that sustainability should be pursued; any locally defined environmental effort would be more successful if it was informed by the residents of the city, and residents would be more likely to buy-in to a project of sustainability to which they had contributed and over which they might feel a sense of proprietorship (Portney 2003). David Hess has explored the link between localism, sustainability and social justice issues, noting that localist movements, while not necessarily geared toward sustainability, invert the long supply chains of the global economy. They reduce the political distancing of consumers from their environmental impact (Hess 2006). Advocates of publicly owned utilities have long argued that public control would result in better alignment of public environmental priorities with power production and conservation decisions (Berman and O'Connor 1996).

The planners and practitioners of sustainable communities have found that participation in sustainability planning not only improved the local appropriateness and quality of the planning but also changes the participants, increasing their commitment to the behavioral and technological changes required (Portney 2005). Private choices in favor of renewable energy and energy conservation often involve concentrated economic costs and inconvenience in order to provide often-diffuse public goods such as reduced pollution. This is analogous to some forms of volunteerism, which is often used as an indicator of civic engagement and social capital (Putnam 2000). The same reciprocal relationship between the volunteer and the cause (the more one volunteers for a cause the more one feels committed to the cause; the more committed one feels, the more one is likely to volunteer) can be seen for those who make changes in behavior and/or technology (Hess 2005). Recent literature in economics and in sociology suggests that social pressures and cultural norms considerably mediate many consumption choices, including those for energy. In fact it is a major tenet of economic sociology that economic activities are embedded in social structures (Granovetter 1985; Veblen 1998). Studies that have focused on social or psychological factors related to energyconservation have shown that values, worldviews and attitudes toward the environment significantly affect the adoption of energy conserving technologies and behaviors (Black et al. 1985; De Young 1993; Gardner and Stern 2002; Georg 1999; Olsen 1983; Poortinga et al. 2003; Stern 1992).

It is precisely at this middle ground between broad market forces, and the countervailing pressures of local social and cultural values and norms that we expect to see the emergence of double movements to create livable communities. For this reason it makes sense to investigate an atypical case. The City of Davis faced the same market forces, the same price signals and the same external political and cultural environment as other cities in California and yet it deliberately and self-consciously behaved differently in many aspects with respect to energy conservation, passive space conditioning, and alternative transportation.

\section{The case}

The City of Davis began as a farming community and a wheat and almond transshipment point in the Central Valley of California. Only eleven miles $(18 \mathrm{~km})$ from the state capitol, Sacramento, Davis is located in the Sacramento River Valley, with alluvial soils and surrounded by some of the most productive agricultural land in the state. The area's moderate Mediterranean climate and flat topography are conducive to biking and passive solar architecture. The city is the home of a University of California campus, a major research and teaching institution which began as an agricultural research station. It is hard to overestimate the influence of UC Davis (UCD) on the rest of the city. It is the major employer and landowner. The resident student population is almost a quarter of the total city population. During the 1960s, the city's population nearly trebled from 8,910 to 23,488 by 1970 , and doubled again by the 1990s. It is now estimated at 65,622 (U.S. Census Bureau 2010a). Davis has striven to maintain its small-town feel, even as it has grown explosively. Davis was one of the first cities to adopt a curbside recycling program, dedicated bike lanes, and energy conservation ordinances. Though it is known for its generally left-leaning politics and lampooned as the "Republic of Davis" where they build tunnels for toads to cross the freeway, it is best known as a bicycle friendly city and the home of one of the world's first sustainable housing developments.

Davis was the first community in the United States to create special bike lanes on its streets and to build a system of dedicated bike paths starting in 1966. The University encouraged biking, by closing its central campus to motor vehicles and by providing extensive bicycle parking facilities. By the mid-1970s, a bicycle culture had developed in Davis. By one estimate, nearly a quarter of all trips were made by pedal power (DeLeuw 1972). But as the population rose, city development expanded, and Davis began to serve as a bedroom community for Sacramento and the San Francisco Bay Area, cycling stagnated. However, bicycle culture persisted, with a strong constituency that pushed City government to fund expansion of bike paths including a freeway overpass, tunnels and pioneering use of dedicated traffic signals for cyclists. The percentage of Davis residents who use the bicycle as their primary form of transportation had been steadily declining since for almost two decades, but the city maintains its identity as the "Bicycle Capital of America." By 2010, the bicycle again accounted for nearly twenty percent of commutes to work (U.S. Census Bureau 2010c) — a testament to the durability of Davis's biking identity.

Davis also staked out an early reputation as an energy-conserving city. It passed, in 1975, one of the country's first energy conservation building ordinances, mandating insulation and glazing levels, north-south building lot orientation for new developments, and energy improvements linked to the sale of existing buildings. With the support of an environmentally aware City council, a young couple built the country's first 
housing development designed to maximize open space, bicycling, solar space conditioning and water heating, community interaction, natural storm water management, and edible landscaping. Village Homes became an icon of green building and sustainable community development that, in many ways has yet to be surpassed. However, Village Homes became a totem rather than the first of many such developments. Several other solar developments were proposed, but none succeeded in Davis. At the turn of the century, the developer of Village Homes proposed an even more ambitious project-a larger solar neighborhood on the edge of Davis that would be even more self-sufficient, integrated, and holistically designed than the his earlier masterwork. Despite the commitment to sustainable design and energy efficiency, the citizens of Davis rejected the development. It is an open question whether Davis' days as an energy conservation and green building leader are in its past.

With the array of social, cultural, political and economic factors that can affect the widespread adoption small-scale renewable energy technologies, Davis offers a useful case to explore their relative importance and functioning. Davis was an early leader in solar heating and bicycling, and maintained its commitment long after the rest of the country had turned toward McMansions and SUVs. As an outlier, Davis can help us understand what factors increase the likelihood of building environmentally sustainable communities and what factors can undermine the longevity of that commitment.

\section{Bike city}

When the University of California at Davis closed its campus core to automobiles in 1966, bicycles were already a distinct part of the Davis lifestyle. North Davis developers were working on a residential subdivision, Covell Park, built around a large greenbelt system of bike paths that connected it to the Davis 'core area'. Bike riding had caught on during World War II, when gas rationing made the bicycle an attractive and practical alternative to the automobile. Bike habits that were developed during the war, survived it. Davis was a natural place for the bicycle, but usage grew towards the 1960s.

One of the most important drivers that propelled Davis towards bicycle dominance was the early enthusiasm of UC Davis' first Chancellor, Emil Mrak (Buehler 2007). Mrak, an avid cyclist, instructed the architects of the University's 1963 Long Range Development Plan to "plan for a bicycle-riding, tree-lined campus" (quoted in Buehler 2007) The campus was planned from the beginning with wide, high-speed bike paths that pass under major streets and link the campus to downtown and all campus extensions. The LRDP included extensive bicycle parking near buildings and separate pedestrian and bicycle throughways. Mrak's invitation letter to incoming students included an exhortation to bring a bicycle to insure that they could get to class on time. The Chancellor's public enthusiasm for cycling and the campus infrastructure he advocated helped to put UC Davis and its students in the vanguard of Davis' burgeoning bicycle culture.

By the early 1960s there were so many bicycles that they were considered a nuisance to pedestrians and motorists, and cyclists began to feel crowded and unsafe. Rapid population growth, increasing car ownership, new roads, and automobile-oriented housing developments led to increased traffic and dramatically worsening bicycling conditions. The chief of police announced a get-tough bike policy, cracking down on two-wheeled traffic violations (Lofland 2004). Eve and Frank Child, recently returned from living in the Hague, presented a petition to the City Council in 1964 calling for "bicycle paths on all arterial streets [and] parking areas in shopping centers" (Lofland 2004). The proposal was flatly rejected by the pro-business City council, which was pursuing a policy of building downtown parking lots to bring in more automobile traffic.

Frank Child, an UCD economist, wrote a letter to the editor of the newspaper The Davis Enterprise in the summer of 1964, describing traffic congestion problems, his family's idyllic Dutch cycling experience, and proposing bike lanes on City streets as a solution (Buehler 2007). A small "Citizen's Bicycle Safety Group" formed around the Childs, meeting monthly in 1964 and 1965. They circulated a series of petitions proposing bike lanes with increasing public support and newspaper coverage. Not only were the conservative Council members hostile to the idea but the Chief of Police and the City staff were opposed as well. The City council created a committee to study the matter, which excluded the members of the bicycle safety group. By 1966 the bike-lane proposal had become a major city issue. In the 1966 election, the two pro-bike lane candidates, Norm Woodward and Maynard Skinner, won by landslides (60 and 68 percent of the vote, respectively) (Lofland 2004). The new pro-bike council immediately voted to begin building a wide-ranging and arterial system of bike lanes in 1966. At the time, the California Vehicle Code contained no provisions for the establishment of special lanes for bicycles, and the state legislature had to pass special legislation to allow Davis to proceed (Larkey 1969). With strong public support behind the council mandate, the City staff embraced the directive to develop bike lanes with enthusiasm. In particular, two City engineers, Dave Pelz and Duane Copley, (hired in 1965 and 1968 respectively) were already bicycle enthusiasts, undertook a systematic redesign of the city so that bikeway design could be standardized and bike-friendly facilities would be integrated into any future developments. The Pelz and Copley era of bikeway development lasted until the late 1990s when they retired (Buehler 2007). By 1968 the bicycle had become such a defining feature of life in Davis that the high-wheeler bicycle was adopted as the City's official centennial emblem (Fitch 1999). 
More importantly Davisites used bicycles as a major form of transportation. A 1970 University transportation survey indicated that 78 percent of students kept bikes at their local residences. A 1972 study co-sponsored by the City and the University found that 60 percent of students, 25 percent of faculty and staff, and between 40 and 60 percent of school-aged children used their bicycles as their primary form of transportation. In all, bicycles accounted for about 30 percent of travel in the city (DeLeuw 1972). This level appeared to have stabilized by the 1980 census, which indicated about 30 percent of Davis residents commuted by bicycle (U.S. Census Bureau 1980). Other famously bicycle friendly cities in California, like Palo Alto and Chico, had less than half that level (approximately thirteen and fifteen percent, bicycle commuting, respectively in 1980). The Davis study, by the consulting firm DeLeuw, Cather \& Co., commended the city for the way its citizens used bikes. "In Davis," the study concluded, "the bike is far more than a recreational toy or exercise vehicle. It is a vital element of the transportation system" (DeLeuw 1972:4). While the study acknowledged the importance of the mild climate, level terrain, wide streets and the presence of many university students underlying Davis' high level of bike travel, the consultants particularly noted "the attitude of Davis residents and City officials" and the legal and physical infrastructure that supported bicycle use (DeLeuw 1972:4).

Over the next two decades Davis maintained its lead in bicycle transportation. In 1986, landscape and urban design professor Mark Francis, and a group of colleagues and students proposed a greenway loop around the city, linked to networks in each neighborhood, that would allow cyclists to avoid interaction with cars entirely. Francis, an enthusiastic resident of Village Homes (discussed below), was inspired by the existing greenway network of bike paths within his own neighborhood (Francis 2003). The proposed change to the city's general plan and subdivision code would require new construction to include greenways, and, by slowly filling in missing links, the city could dramatically upgrade its alternative transportation infrastructure to benefit cyclists of all ages and skill levels. The greenway would also serve as an extensive linear urban park linking Davis communities to open space, natural habitat, and recreation areas. The greenways offered an opportunity to satisfy the pervasive local desire to preserve open space and improve the bicycling infrastructure (Jones 1989). After initially meeting with little public enthusiasm and rejection by the General Plan Update Committee, Francis managed to persuade the UC Davis Chancellor and two progressive City councilors to support the plan (Francis 2005). Most parts of the planned greenways were built by 2007, primarily by enforcement of the subdivision codes. This made the greenways a project with a high amenity level and low cost to the city.

In 2005, the League of American Bicyclists gave Davis the highest level of recognition for its bikefriendly policies, but by then cycling advocates had been worried about declining participation for a decade (League of American Bicyclists 2005). By the 1990 census, bicycle commuting had fallen to about 22 percent of workers although it had declined only insignificantly in absolute numbers - a difference easily explained by Davis' population growth (See Figure 1). The trend continued, and a decade later, in 2000, while still high in comparison to other cities, bicycle commuting in Davis had declined both relatively and absolutely to approximately 4,490 bike commuters, or about 14 percent of the workforce (U.S. Census Bureau 2000). The decline in bike use over the 1990s and into the 2000s was obvious to the everyday observer (Lofland 2004:155; Parker 2003).

Why did Davis residents at one point choose to use bicycles as a major form of transportation to a much greater degree than other Californians, and why did a smaller portion of them choose to do so during the 1990s? What might have driven the resurgence of cycling toward the end of the first decade of the new millennium? Many other California cities have flat topographies and pleasant Mediterranean climates and neither characteristic has changed during the human history of Davis, so these factors form a favorable constant background for cycling. Factors that do explain change fall into three non-exclusive categories: economics, demographics and the politics of culture and identity.

\section{Economics}

The price of oil peaked in 1982 and declined rapidly during the 1980s as new oil sources flooded the market. By 1988 the retail price of gasoline reached its lowest point in inflation-adjusted dollars since 1972 (EIA 1998:Table 5.22). In addition, due to the introduction of federal CAFE standards, cars could go almost twice as far on a gallon of gas in 1988 as they could in 1972. This sent an obvious price signal to get Americans back in their cars. Americans not only began driving more, but they also began driving farther to commute to work. However, in Davis, bicycle commuters remained almost constant in numbers, even as they fell as a percentage of the workforce. Among students, a major component of the cycling population, growth in public transit use may have also been a factor. In 1992, the student government voted to replace fares with unlimited ridership for a fixed fee. Soon thereafter ridership on Unitrans increased rapidly and bicycle ridership simultaneously declined (Buehler 2007). 


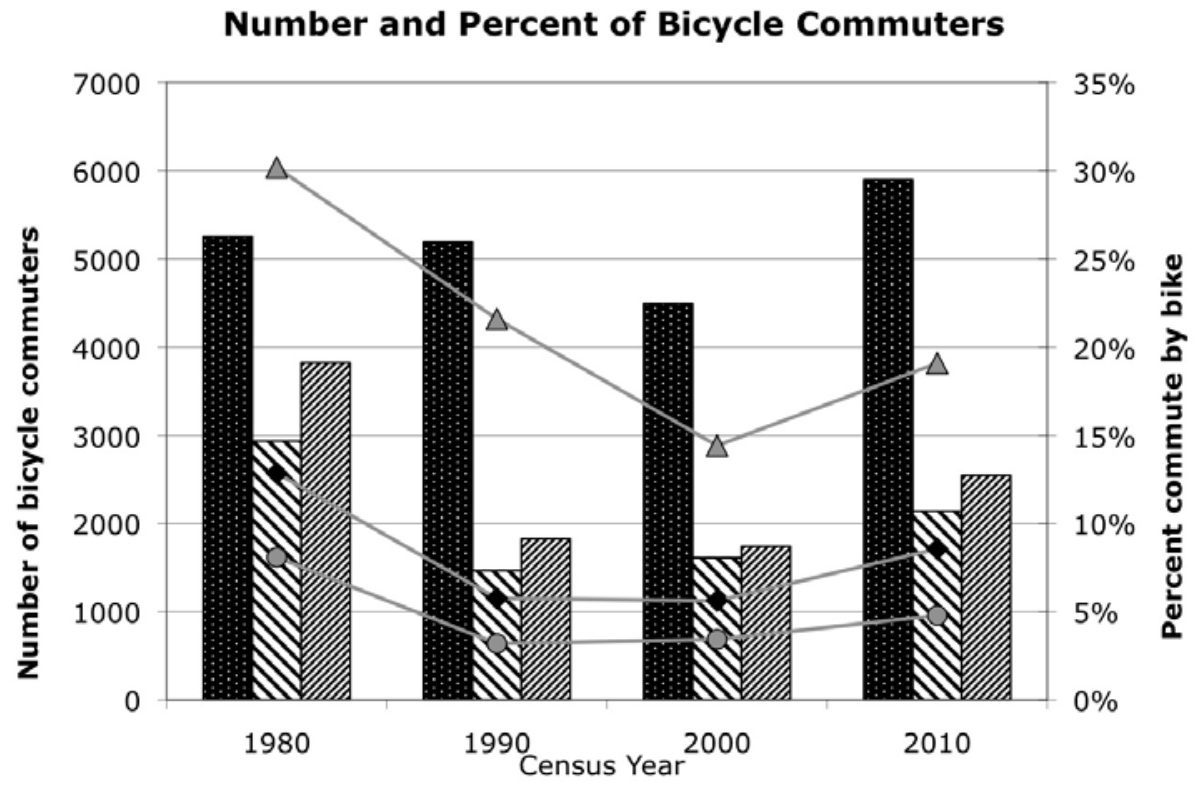

Davis $₫$ Santa Barbara $\mathbb{U}$ Palo Alto $\triangle$-Davis - - Santa Barbara - Palo Alto

Figure 1: Bicycle commuters in Davis and comparison cities (Bars are numbers. Lines are percents). Sources: U.S. Census Bureau 1980, 1990, 2000, 2010.

\section{Demography}

Most of the bike commuting, as with most other economic activity in Davis, can be attributed in some way to the University. Despite the city's slow growth policies, it has grown significantly with most of the new housing built in the western and southern parts of the city. This has resulted in greater travel distances from residences to the Davis core area and University campus. The profile of Davis residents and people who work in Davis has also changed. Increasingly, newer residents of Davis are commuting to Sacramento or the Bay Area to work. This accounts for the quadrupling since 1990 of Davis residents who commuted by train a decade later (U.S. Census Bureau 2000). Conversely, as the city's cost of living and real estate prices have increased (partly due to the amenities and reputation related to biking), people-including students-who study and work on campus are less likely to reside in town. "Davis is changing from a small college town to more of a bedroom community," says UC Davis Bicycle Program Coordinator David Takemoto-Weerts (Parker 2003). "Simply, there are fewer people who both live and work in town, and can therefore consider biking as an option." While Davis' growth has increased commuting distances, it has also prompted an improved bus service. Bus ridership almost tripled during the 1990s, increasing from about three percent of workers in 1990 to almost seven percent by 2000, and possibly accounting for more than half of the decrease in bicycle commuting (U.S. Census Bureau 1990; U.S. Census Bureau 2000). Bus ridership held steady at just over seven percent in 2010, implying that the additional bicycle commuting population did not draw down the population of public transit commuters (U.S. Census Bureau 2010c).

\section{Politics, Culture, and Identity}

By 1972, the majority of the bikeways had been completed. One could now safely and conveniently ride a bike to any city destination, and most people did so on a regular basis. The city promoted cycling and bicycle safety through education programs in the schools. A core group of long-term public works staff had extensive experience with—and commitment to-designing and building bicycle infrastructure. When the 
last of these, Dave Pelz, who had been on the public works staff since some of the earliest bike lanes were built in 1967, retired in 1999, there was no longer any experienced bicycle advocate on the City staff. Pelz hired a full-time bicycle coordinator to insure that the City had some expertise and advocacy for continued bicycle facilities development, but he has been a lonely voice (Buehler 2007). Having a bicycle coordinator indicates a deeper commitment to cycling support than most U.S. cities, but the need for a special position indicates a missing advocacy coalition in the regular City staff. The retirements of the founding bicyclesupporting generation included retirements at the state level as well. The state's long-time bicycle program director, Rick Blunden, a life-long Davis resident, retired in 1999. There was a decline in the coordination with CalTrans public transport programs, and the City staff's sense of leadership also dropped-the feeling that they were exporting the Davis model to the rest of the state.

The social and cultural aspects of cycling tend to operate as positive feedbacks. When your friends are biking, you are more likely to bike with them. Like a rolling snowball, the loose network of fellow cyclists expands, and with it the likelihood that someone you know uses the bike as a primary form of transportation-increasing your likelihood to bike as well. The increased level of cycling in town leads to increased demand for bike paths, and increasing levels of support for bicycle facilities. This, of course, makes biking more convivial and attractive, which increases the number of cyclists, etc... If, however, more people begin riding the bus, the same positive feedbacks lead to increased bus ridership, expanding bus fleets, increased funding for transit, better service, and thus more riders... As the city expands, more people live too far from downtown, or campus, or their places of work to comfortably commute by bike. The bus or a personal car becomes more attractive. The positive feedbacks decrease the social pressure to bike and begin to shrink the cycling network. As the number of people who work outside town and commute by car increases, the likelihood that your neighbor commutes by bike decreases. This similarly triggers the feedback loops to decrease cycling, cycling facilities support, and the entrained social networks. When it is "normal" to cycle, more people cycle. When it is "normal" to take transit or drive a car, more people chose those modes.

In the 1980s heyday of cycling in Davis, conflicts between motorists and cyclists were practically unheard of. Everyone biked, and everyone knew cyclists, so there was a tendency to respect the needs of fellow cyclists even while driving a car (Buehler 2007). Recent anecdotal evidence, including the author's own experience, suggests that cyclist/motorist conflicts are increasing even as the ratio of bikes to cars decreases (Buehler 2007; Sommers 2003). Some observers have suggested that this is because increasing numbers of motorists in Davis do not ride bikes (Sommers 2003).

Davis maintains its identity as the bicycle capital of America, but it is not clear that this is as strong a source of identity for Davisites as it once was. Older residents are the more dedicated cyclists, while newer residents tend to drive. One long-time cycling advocate noted that in his department at the University "it is the older faculty who are the dedicated bike riders, while newer faculty drive cars." Perhaps the older faculty members are simply more persistent out of habit, or they live in older neighborhoods closer to campus. Perhaps the newer faculty members commute to Davis from out of town. Regardless of the cause, there appears to be a generational split, in which older Davisites identify passionately with the bicycle and continue to be engaged with the civic life of the city as cyclists. Newer residents identify less with the bicycle and with Davis, than with other priorities (Lofland 2004). The effect of the city's growth and demographic changes on support for cycling is explored in more detail later in this article.

Davis is still one of the most bicycle-friendly cities in the United States. The topography and climate as well as the physical and cultural infrastructure that the City built over almost half a century have made bicycle transport one of its most tenacious features. Without these features, biking in Davis might have declined even more than it did, and would not have rebounded in the late 2000s. However, Davis' long-held position as a national leader in cycling also may have led to complacency. Cycling advocate Ted Beuhler has documented an attitude among City staff and cycling advocates alike that Davis has done all it can do, and can rest on its laurels (Buehler 2007). The City's bicycle coordinator, Tim Bustos, said, "We've really done as much as we can really do for bicycle facilities... we're really approaching build-out" (Bustos 2005). However, increased automobile traffic has rendered obsolete some arterial bike lane designs that were once innovative and effective (Landis et al. 2003). In 2005, the City organized a Bicycle Advisory Commission. The commission has studied various options for expanding bicycling facilities including connections to other cities and areas outside Davis. In 2009 it adopted a City Bicycle Plan, for which "the primary goal... is to increase the amount of bicycle trips as a percentage of all trips to $25 \%$ by 2012, a level formerly achieved in 1990" (City of Davis 2009). Enthusiasm for some of these newer projects may be leading to a renaissance of bicycling in the city, as intended by the commission.

\section{Solar City}

Since the late 1970s, Davis has been associated with solar energy. This is mostly attributable to the world renown of Village Homes, a green building development finished in 1981 that was designed to conserve energy and promote community. However, before the Village Homes project was begun, Davis had already taken the lead in energy conservation and solar energy. In 1973, Davis became only the second city in California to adopt a General Plan that was designed to control growth. The new housing allocation system 
permitted "city planners to choose only the best, most energy-conserving subdivision proposals" (Jacobsons and Corbett 1978:3). In 1975, Davis passed an Energy Conservation Building Ordinance (ECBO), which required the north-south orientation of all new construction and encouraged solar space and domestic water heating. A City booklet describing the plan declared it "the first energy conservation building code in the country" (Jacobsons and Corbett 1978).

A study of the effectiveness of the ECBO, which used neighboring Woodland as a control to correct for weather effects, energy price changes, and non-local policies, revealed a fifteen percent reduction in electricity consumption in the first 41 months after the policy was implemented (Jan 1, 1976) (Dietz and Vine, 1982). This reduction was "attributed to both the structural features of the code and to the energy conserving behavior of the residents of the city" (Dietz and Vine 1982:755). In fact, most of the difference between Woodland and Davis energy consumption could be attributed to energy conserving behavior and building (energy conservation upgrades, etc.) in Davis that occurred before the implementation of the ECBO (see Figure 2). Approximately 60 percent of the reduction in per customer electricity use in Davis between 1973 (the year Davis began to diverge significantly from neighboring cities) and 1978 (the year beginning Dietz and Vine's data) was accomplished before the implementation of the ECBO in 1976. Moreover, the very hot drought year of 1976 caused a jump in electricity use. If we omit the unusual year of 1976, we see that Davis continued its energy conserving trajectory that held before and after the ECBO came into effect.

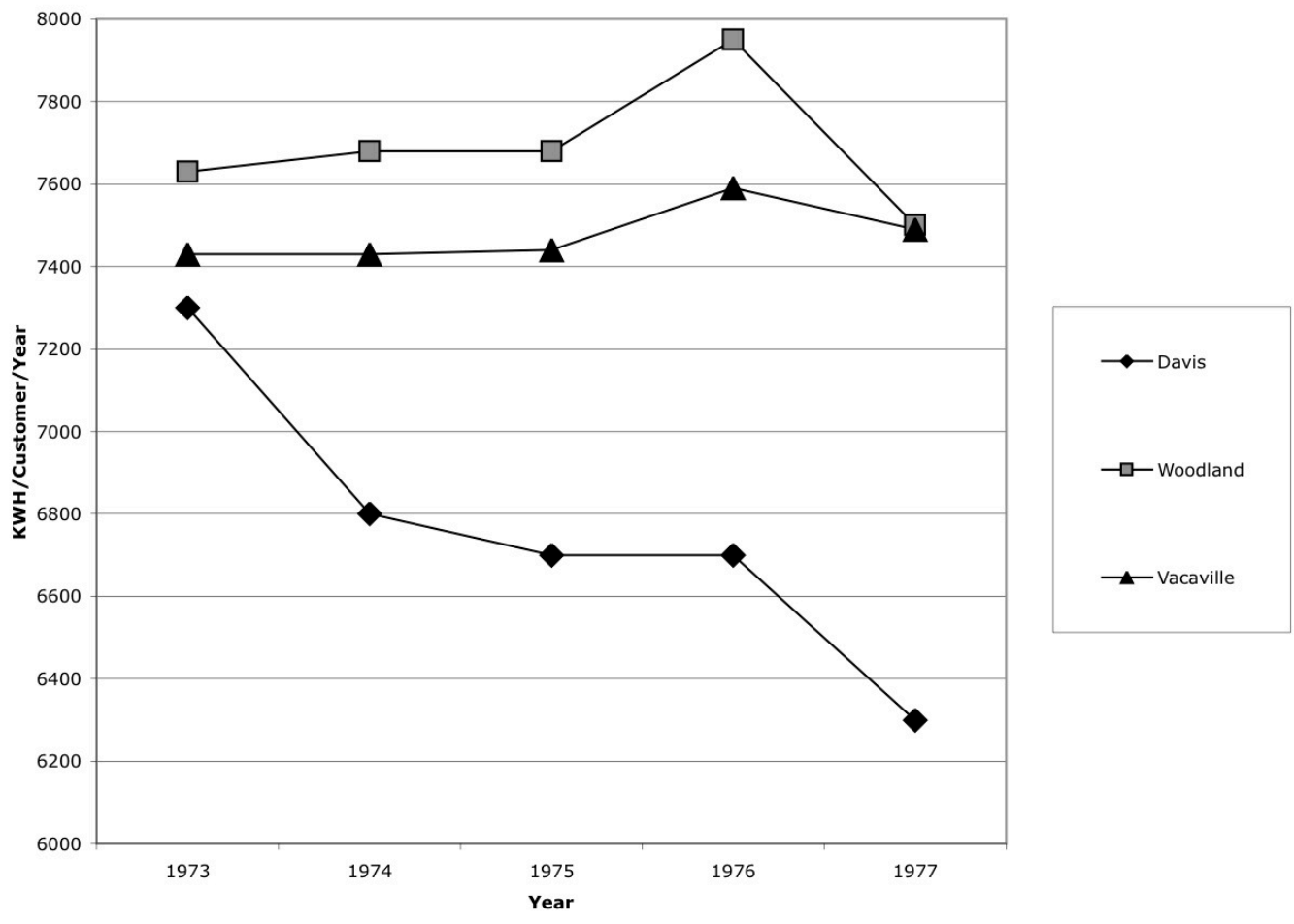

Figure 2: KWH usage per customer per year. Source: Hammond et al. 1980.

This is unsurprising. The adoption of the ECBO was a popular move. The ordinance was adopted unanimously. As Jim Stevens, a conservative who frequently found himself on the losing side of 4-1 votes in the progressive City council elected after 1973, recalled, "[w]e could all see the advantages of an appropriately drawn energy ordinance, and, therefore, the big struggle was: what does appropriately drawn mean?" (Fitch 1999: Ch.2). In fact, in 1973, the council had commissioned a study of thermal performance and energy use of actual buildings in Davis (Hammond 1974) to determine the most important design features to "all but eliminate the need for summertime air conditioning" and "substantially" reduce "the need to heat residential buildings" in winter (City of Davis 2007). It was clear that Davisites were already interested in energy conservation, had gained considerable experience with it during the early 1970s, and were well disposed to believe that better energy conserving design and retrofit could be required "without unduly restricting designs and raising costs, or requiring new technologies" (City of Davis 2007).

The most ambitious attempt to employ the principles outlined in the ECBO was begun before the adoption of the ordinance. Village Homes, which still stands as a unique model in green architecture and community design, began construction in 1975 and achieved plan build-out in 1981 (Corbett and Corbett 2000). The development, starting from its design inception in 1972, incorporated all of the principles in the ECBO, but went much further. The layout of the community allows all homes to face south to maximize 
solar heating in winter and minimize it in summer. The narrow streets and strategically placed deciduous tree plantings maximize shading and keep houses cooler in the summer. The homes include a variety of styles and sizes and include a variety of passive or active solar heating systems. Most also have solar water heaters, which heat all of the hot water for the houses seven months of the year and provide 40 to 50 percent of the heat during the remaining months (Corbett and Corbett 2000). One early study showed that Village Homes residents used just over half the amount electricity used by PG\&E customers in other parts of Davis, and just under a third of that consumed by residents of nearby Woodland (Hamrin 1978). Village Homes residents used one third less natural gas than other Davisites, and almost 50 percent less than Woodland residents (Hammond et al. 1981). This was still the case in 1990, almost a decade after build-out (Lenz 1990). Largely due to its energy conserving and solar features, Village Homes became an international model of sustainable development, drawing celebrities and an annual procession of architects and city planners from all over the world.

Village Homes began as the project of an energetic graduate student couple, Michael and Judy Corbett, who overcame a number of obstacles through a combination of good timing, political connections, and missionary zeal. Local historian John Lofland describes the "Village Homes story" as "the triumph of vision, goodness, and persistence over narrow-mindedness, risk-aversion, and bureaucratic rigidity (Lofland 2004:141)." The Corbetts, in their own assessment, credit the growing environmental consciousness in Davis and the makeup of the City council after the 1972 election (Corbett and Corbett 2000).

The "revolution" of 1972 transformed the City council from a conservative, business-oriented bastion of men in suits to a progressive coalition including a female lawyer and mother, a liberal Democratic activist and director of environmental health at UCD, and the recent president of the UCD student body, an organic/health food store owner (Lofland 2004). The last, Bob Black, who had been instrumental in closing UCD central campus to automobiles and bringing in iconic double-decker buses, was a member of the Greater Davis Planning and Research Group (GDPRG), which included Michael and Judy Corbett. The group, largely made up of ecology graduate students, put forth a platform of stopping urban sprawl, preserving agricultural land, reducing the area devoted to streets and parking lots, and revising the City's general plan. First Bob Black, and then the other two progressives, Joan Poulos and Richard Holdstock, embraced the GDPRG platform.

Despite a newly sympathetic council, gaining approval for many of the more innovative features of the Village Homes plan required a massive effort. The City staff objected to almost every feature of the planned development from narrow streets and inward-facing homes to natural drainage systems. The Corbetts successfully countered each of the staff's objections (often with practical physical demonstrations and field trips) and were able to persuade the City council. Still, as they acknowledged later, "it is a rare city council that is willing to go against the recommendations of its staff." The entire process," they wrote, "taught us that change must originate with local elected officials" (Corbett and Corbett 2000: 25-26).

Davis appeared to have embraced its identity as an energy conserving city (and a solar one in particular) during the 1980s. Davis began the decade with a higher proportion of houses using solar heating than any other California city within an order of magnitude in population size (U.S. Census Bureau 1980). By 1990, the number of solar heated houses had increased almost seven-fold and represented almost two percent of housing units in Davis (U.S. Census Bureau 1990). While 325 solar heated homes may seem like a small number and a small reduction in fossil energy use, if 1980s growth rates in housing and solar heat had remained constant through the 1990s, Davis would have had 2,200 solar heated homes by the year 2000, representing almost ten percent of housing units. Moreover, one can imagine that as familiarity with solar technologies increased and as more local builders, developers, and architects gained experience, the increase in solar heated housing might have been exponential rather than linear. However, this is not what happened. By 2000, with accelerating housing growth rates and utter loss of national and state incentives for solar heating, the number of solar heated houses not only failed to grow, it actually declined by thirty percentrepresenting less than half a percent of housing units (see Figure 3). A decade later, solar heated housing continued its relative and absolute decline in Davis (U.S. Census Bureau 2010b).

With all its success and fame, the great nagging question about Village Homes is why no similar development has been built since. The secular trends against green design and community development in the United States as a whole might be sufficient to explain the inability of the Village Homes model to spread, but the fact that no similar development was built in Davis is harder to explain. Community Development Director Jeff Loux and Associate Planner Robert Wolcott noted that "[m]any citizens throughout the city look with pride to Village Homes and question why no similar model has been built in the past 20 years" (Loux and Wolcott 1994). Among the possible reasons Wolcott and Loux offered were the increase in land prices, changes in home styles and tastes, and rigid city standards.

In fact, in 1980, just over a mile northeast of Village Homes, another site of approximately the same size was being planned as another solar neighborhood. Jon Hammond, lead partner of a company called Living Systems, had submitted plans for building Senda Nueva, a residential development that promised to champion many of the planning principles pioneered in Village Homes while introducing several innovations of its own. "Over the last few years, Davis has led the nation in the field of innovative planning and solar design," Hammond explained in a 1980 letter to Fred Howell, the City's planning director at the time. "We at 
Living Systems feel that it is important to continue this work. I believe that we have just begun to explore the possibilities of living a better life, more in harmony with the landscape and each other, yet using fewer nonrenewable resources" (quoted in Fitch 1999). Senda Nueva was to have twice the housing density of Village Homes, more apartments, condominiums, and cooperative housing to supply more low-income housing. "Virtually every feature of this neighborhood will be designed for energy and resource conservation," Hammond explained in a June 1980 project description. "Solar, natural and human energy will be substituted for fossil fuels wherever possible" (Hammond 1980:1).

Residential solar heating in Davis and comparison to California

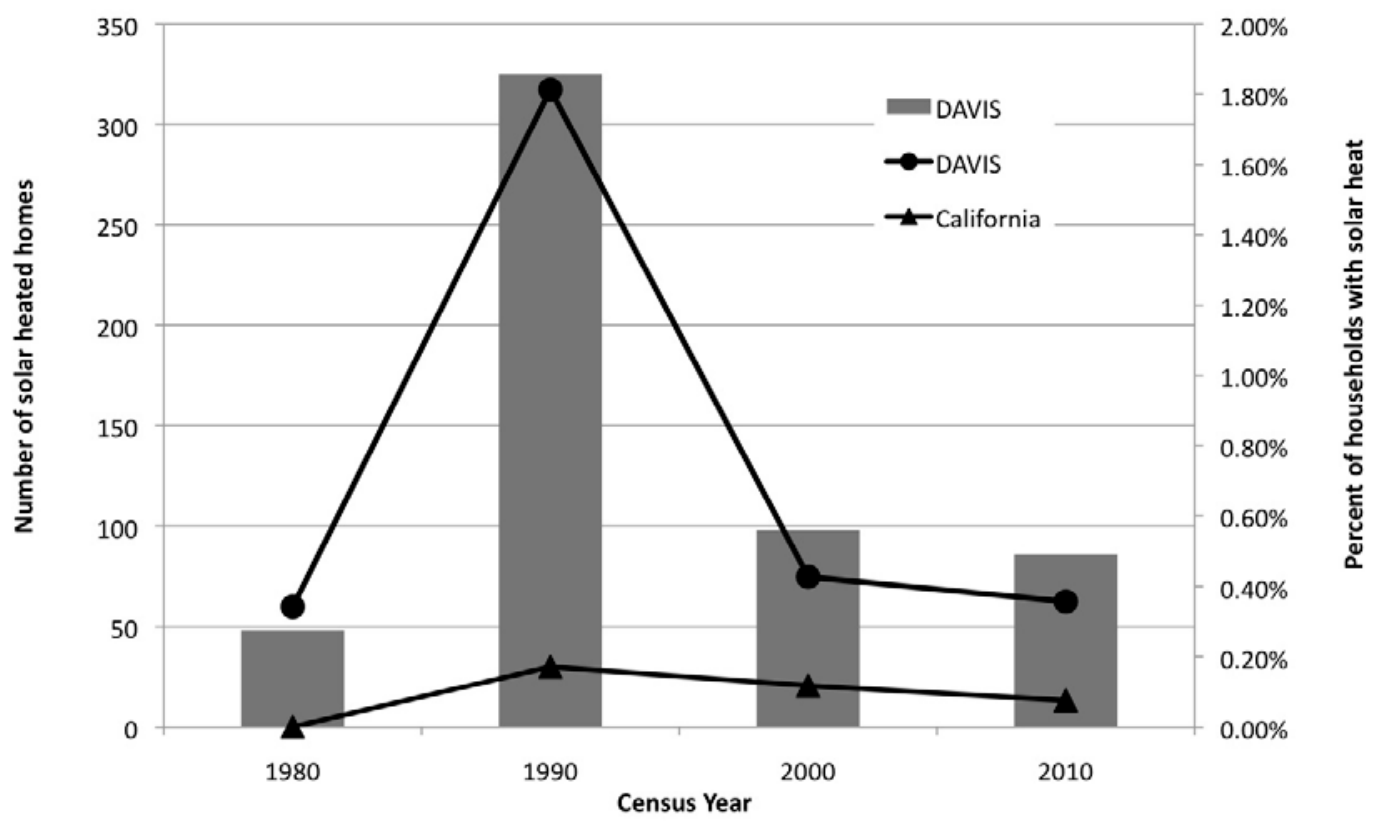

Figure 3: Residential solar heating in Davis and comparison to California (bars are numbers, lines are percents). Source: U.S. Census Bureau 1980, 1990, 2000, 2010.

If any solar neighborhood development should have succeeded it was Senda Nueva. It shared many features with Village Homes, which by 1980 was a clear success. Not only did it conform with the new ECBO, Senda Nueva's designer was the primary consultant and author of the report that led to Davis's pioneering ordinance. The proposal included an urban forest and agricultural preserve, which happened to be precisely the sort of measure recommended at the time by the City's Ad Hoc Alternative Land Use Committee. Like Village Homes, Senda Nueva would emphasize biking and walking with all houses reachable without crossing a roadway, and narrow streets to reduce traffic speeds and storm runoff while allowing increased tree shading in the summer (Hammond 1980: 2). Moreover, the developer had, if anything, more credibility than Michael Corbett. He was the primary author of the California Energy Commission's (CEC) guide to Planning Solar Neighborhoods (Hammond et al. 1981). One of the partners in Living Systems, Marshall Hunt, was also on the Planning Commission. In addition, a major hurdle that almost prevented the Village Homes project from going forward was financing. In 1975 lenders had no experience with solar homes and little inclination to finance the construction of solar developments. By 1981, there were several state supported financing structures specifically designed to support the development of solar energy, including the Solar Business Investment and Development Corporation (SAFE-BIDCO), a solar mortgage corporation (Sunny Mac), a municipal solar utility and a Public Utilities Commission mandate for PG\&E to finance solar installations, and an outreach and education program from the CEC aimed at lenders. All this should have made Senda Nueva easy to finance and approve.

The project was, however, quickly beset by problems. Residents of nearby neighborhoods objected to the two five-storey buildings and wanted to move the urban forest so that it would no longer function as a buffer between Senda Nueva and a major road, but rather would function as a buffer for their own neighborhoods. Remarkably, considering Village Homes' demonstrated success, they objected to the narrow cul-de-sacs on the basis of police and fire department emergency access. City planning staff tended to agree with these objections. At each stage of the City review process the ambitious solar neighborhood lost controversial features and became a much more conventional project. Eventually, the project became 
unrecognizable and John Hammond withdrew (although he did design the successful, passive solar, cooperative housing project, Dos Pinos, which is part of Senda Nueva) (Stello 2006).

One of the City's leading developers, John Whitcombe, claimed that "[t]he main reason there aren't more Village Homes is there's only one Mike Corbett" (quoted in Fitch 1999: Ch. 4). This contention received a direct test in 2004 when Mike Corbett became the primary designer and public face of a 383 acre (155 ha), 1,864 home, mixed-use development proposed for a plot of agricultural land north of Davis's border. The project would have been the largest ever built in Davis - ten times larger than Village Homes. It would have required annexation of the farmland and would have altered the City plan. Corbett had designed the project according to "new urbanist" principles to be largely self-contained, with offices, stores, restaurants, parks and schools all easily within walking and biking distance for the future residents. Most buildings would have featured some form of solar climate control, domestic water heating, and integrated solar photovoltaic (PV) panels. The developers, who included Corbett and Whitcombe, easily persuaded the City council to support the development, but a new law passed by referendum in 2000 required any conversion of agricultural land to be put to a citizen vote. In November 2005, the citizens of Davis rejected Measure X, preventing the development from going forward.

Understanding why the City council and one of the City's most prominent citizens (a former mayor known for his work on sustainable development) failed to persuade the citizens to support a carefully planned, bikeable, solar neighborhood in response to the problem of the city's rapid growth may offer a key to understanding the changes in political culture that underlie Davis's declining rates of solar energy usage and (until recently) bicycling. Before the election, the import of the vote was apparent to many observers. One reporter, asked, "... have sprawl, housing costs, and simply time skewed the city more conservative, causing it to look more like an Elk Grove than a Santa Cruz?" (Barker 2005). The "yes on Measure X" group portrayed Covell Village as smart growth and a way to prevent less environmentally benign developments from appearing on the city's borders. Opponents sought to portray the development as an elitist land-grab by profit-driven developers that would cause Davis to grow too big too fast. The "Yes on X" forces emphasized the bikeable, self-contained nature of the development and the promise of solar panels and pre-installed solar infrastructure that would satisfy an average of 30\% of the development's electricity demand. However, the debate centered on how the city would control its own growth. It was widely felt among Davisites that the vote on Measure X was about the Davis identity. It was a referendum on how they would define "slow growth", how a "pro-environment" community would deal with the environmental problems of population growth, what version of "progressive" would define Davis' politics, and whether Davis would really identify as clearly progressive as it had in the past.

The opposing camps presented two versions of the 'environmental progressive'. One, represented by Corbett, emphasized the regional and global environmental benefits of designing a large development in a sustainable way and preempting other less responsible and sustainable developments. The plan for Covell Village held fairly close to the Ahwahnee Principles of sustainable urban planning (Calthorpe et al. 1991), that have become a standard point of reference for New Urbanism and the EPA Smart Growth initiative (New Urbanism 2009). Solar energy advocates were also enthusiastic. The City council and other "yes" forces emphasized the threat of less controlled growth at the city's borders. "If you vote no on X," City Council members Don Saylor and Stephen Souza wrote in an email to Davis residents, "you are encouraging Sacramento developers like Steve Gidaro to build sprawl in every direction around Davis." The city had experience with developers doing an "end-run" around authorities by getting approval from the county to build on the city borders when developer Frank Ramos got approval for the development of Mace Ranch in 1988 (Fitch 1999: Ch. 6).

Despite these environmental selling points, the local Sierra Club and Green Party opposed Covell Village. They felt that the development would be too much growth too fast. They objected to the loss of agricultural land, worried about impacts on traffic, and felt that the development wouldn't offer enough low cost housing. Anti-X forces tapped into a long simmering Davis tradition of opposing growth. About a decade earlier, the fight to prevent the development of Wildhorse, a housing and golf-course development, similar to Mace Ranch, had taken on the feel of a last-ditch campaign to protect the small-town character of Davis against money-hungry developers willing to take the community down the path of rampant growth. "Good cities are rare! Let's not rush to lose ours," urged the Wildhorse Opposition Association literature during the 1995 referendum (Fitch 1999: Ch. 7). The Davis slow growth/no growth political tradition was in direct conflict with the city's pro-solar past. The progressive community was deeply divided and the debate often acquired an angry, strident tone with ad hominem attacks coming from all sides. Measure X was a quandary that threw into question what it meant to be a Davisite.

In the end the vote was primarily a NIMBY ("not in my back yard") response to the problem of urban growth. On a precinct by precinct basis, distance from the proposed site of Covell Village was the strongest predictor of how large would be the margin in favor of the "no" on X position $(r=-0.554, p<0.001)$, i.e., the closer to the proposed site, the larger the margin against Measure X. Richard Harris, the "View from South Davis" columnist for The Davis Enterprise, captured the importance of distance and the fact that concern about Covell Village was about the potential negative local effects, rather than the potential environmental 
benefits on the regional scale. "For SoHo," he wrote, "Covell Village is just a fight over a housing project that is farther from our lives and will have less impact than thousands of Solano County cows" (Harris 2005).

Some, including Corbett, have suggested that much of the opposition to Covell Village came from newcomers. "There are a lot of people who have moved in from out of town who I wouldn't describe as 'progressive'... they're not sure they want more people here" (Barker 2005). Even an opponent of Covell Village who has lived in Davis since 1966 and has also served as Mayor, Ken Wagstaff, recognized that a large portion of his coalition included people who were not part of the historically progressive Davis community. "There are people who buy a home in Davis because they can't afford to buy in the Bay Area. It's near the freeway. They don't spend much time in town. They don't take the local newspaper. They could just as easily live in West Sacramento or down by Clarksburg," he said. "Growth doesn't bother them unless it comes right to their doorstep" (Barker 2005). The hypothesis that residents of newer subdivisions would be more likely than those from older parts of Davis to object to another subdivision was not proved, since there was no correlation between ward annexation date and the "no" vote's margin of victory as a percentage of the total vote $(r=-0.36, \mathrm{p}<0.819)$.

This does not, however, preclude the idea that more recent immigrants to Davis might have been more likely than longer-term Davisites to object to a new subdivision, or, specifically, not to value the solar and energy conserving aspects of the proposal enough to override their disinclination to allow another subdivision. This could be explained in two ways that are potentially related: (1) newer residents want to preserve property values, and (2) they tend to be more politically conservative with the attendant disdain for renewable energy, conservation, and environmentalism that has become typical since the 'Reagan Revolution'. "It's the new-to-town Republicans that are the biggest NIMBY conservatives," said longtime Davis Enterprise columnist, Richard Harris. "They're the last ones in and they want to close the gates behind them because they want to protect the values of their homes" (Barker 2005). ${ }^{2}$

Although the percentage of voters registering as Democrats and Republicans has declined only very slightly in the past half decade, the number who decline to state a party affiliation has grown by $67 \%$ from 1999 to 2005 (from 15\% to 23\%). This mirrors the trend statewide, but is greater (McPherson 2006). It is conventional wisdom that "decline to state" voters skew conservative, so it is unsurprising that there is a highly significant correlation between George Bush's percentage of the 2004 vote in a precinct and the recentness of the area's annexation to the City of Davis $(r=0.496, p<0.001)$, i.e., the newer the subdivision, the greater the percentage of Bush voters. The only precinct in which George Bush won in 2004 is also the only precinct farther than a mile from the site of Covell Village in which the margin of victory for the "no on X" position was more than $30 \%$ of the total vote. There is some evidence that Davis' new "stealth Republicans" were a significant factor in the rejection of Covell Village. In precincts farther than 1.5 miles $(2.4 \mathrm{~km})$ from the proposed Covell Village site (to control for the effects of proximity), the percentage of the vote that went to George W. Bush in 2004 is moderately, but significantly correlated to the margin of victory for the "No on Measure $X "$ position as a percentage of total votes $(r=0.445, p<0.034)$. With the majority "progressive" community split, it possible that the new conservative vote made the difference in rejecting Measure $\mathrm{X}$ and Covell Village.

\section{Discussion}

Local historian John Lofland has identified three different recent phases of Davis' identity. In the late 1960s and early 1970s, Davis discovered or invented its identity as 'Bike City.' In the 1970s, "events converged in a way to make it possible to incorporate bikes into the wider and more serious identity of energy use innovation and conservation. 'Eco-City' (as in ecological) took its place alongside or even above 'Bike City'" (Lofland 2004:154). Over the 1990s and 2000s, he observed the "marked decline in bike use" and that Davis "stalled" in energy conservation and solar energy standards and practices. By the later 1990s, the city's identity became "Weird Davis" (Lofland 2004:154). These identities correspond roughly with the designations Lofland uses to characterize the ideological makeup of the City council over time. From the 'revolution' of 1972 to about 1989, the City council was dominated by progressives; during the period since 1990, the council has been dominated by "moderates"—a period Lofland describes as "Contested Davis" (Lofland 2004: 135-45). Of at least symbolic importance, 1990 was the year that incumbent mayor and progressive Mike Corbett was defeated.

In the late 1970s through the 1980s, the City of Davis created and developed its identity as a city that favored human powered transportation and solar heated residences. It became an internationally known model of sustainable urban development. Several forces and circumstances combined to make this possible. The area was blessed with a moderate Mediterranean climate and flat terrain, which made passive solar design effective and cycling easy and convenient. The combination of two energy crises, the flowering of the academic field of ecology, the growth of environmentalism, and a state government actively promoting appropriate technology, solar energy and energy conservation made a university town in late 1970s California most likely to embrace a sustainable city agenda. A core of young, charismatic, entrepreneurial

\footnotetext{
${ }^{2}$ See Beebe and Wheeler (2012) in this journal for a discussion of changing residential property values and the attitudes of established residents in El Dorado County, east of Sacramento.
} 
individuals worked in and out of City government to create a model solar neighborhood, supporting building ordinances, and an infrastructure of bike paths and municipal codes that favored cycling. Combined with outside pressures, the very quality of life they created in Davis drew in additional residents and caused the city to expand quickly. The rapid demographic and spatial expansion of the city led to changes that threatened the continued viability of its primary identity as a haven for cycling and solar architecture.

One of the primary lessons offered by this case study is that scale matters. While it is easy to see how enhancing civic engagement and developing a local identity around sustainable technologies and practices is translatable to any small city, it is not clear whether this model can "scale up". It does seem that there are virtuous and vicious circles related to civic infrastructure and growth. Cities like Davis, with a clear downtown core, have a greater chance of encouraging broad civic engagement and civic identity than do 'sprawl cities'. Sprawl cities, where the majority of residents may only rarely visit the urban core or whose work, entertainment, social, and identity commitments are not tied to the city, are unlikely to be able to motivate residents to adopt renewable energy technologies and behaviors at a personal or household scale.

As one of the most commonly cited examples of successful green development, solar housing design, and human powered transportation, Davis offers a glimpse of the complex interaction of factors necessary to the production and successful long-term implementation of renewable energy policy that impact lifestyle choices. In the case of bicycle policy, Davis' long-term commitment resulted in a fairly stable (and high) level of participation-effectively making a permanent reduction in automobile traffic in the core areas. Davis' commitment to solar housing design had a shorter gestation and also a shorter lifespan. Unlike the bicycle, solar design never became a persistent part of the Davis identity.

One lesson from Davis's relative successes is that technologies thrive where they are already a good fit. In the case of bicycles, Davis was perfect with its core area, university, and flat terrain. Its Mediterranean climate was also perfect for passive and active solar buildings. However, cycling is well adapted the small, college town feel of Davis and it introduced a social and sociable aspect to transportation that appealed to that sensibility. Solar, by contrast was associated with alternative lifestyles and off-the-grid rural hippie communes. It worked well as applied to Village Homes partly because of the social aspect integral to the whole housing development. A solar home was as much a part of the infrastructure as the communal gardens, grassy paths, and playgrounds. Outside of such a whole-system-designed context, solar heating became a solo enterprise, an optional add-on with few social rewards and many risks and unknowns.

When communities envision a desirable future it is not enough to put in place policies such as building codes and long-range development plans. Their ability to achieve that future state will have to withstand unfavorable internal and external forces. They must build policy momentum. This means making elements of the communities' collective ideal part of all of its residents' collective experience. This is why the infrastructure and culture of biking had such longevity in Davis, while that of solar heating did not. I think it is reasonable to speculate that if Senda Nueva had been built as a solar neighborhood, the experience, local expertise, and sense of trajectory would have made it possible for developments such as Wildhorse to have been designed as solar neighborhoods. It is possible that without the negative experiences of some of the newer, energy intensive developments, residents would have welcomed Covell Village and its solar features rather than fearing the coming of another mega-development.

One of the forces with the greatest potential for disruption or benefit is policy at higher levels of government. Pro-solar policies at the state and federal level helped to create the environment for the solar industry to grow, but the sudden end of these policies killed the industry. This means that local governments need to devise ways to shield their own industries and policy objectives from the vagaries of federal and state government. In the case of solar, Davis could have maintained its municipal solar utility (as Santa Clara did elsewhere in California) despite the end of the tax credits. This would have acted as a buffer between solar customers and the turmoil in the industry. It would have retained a trained staff to maintain solar systems, probably allowing far fewer of the latter to fall into disrepair. Santa Clara's Municipal Solar Utility (in which the City of Santa Clara leased solar hot water heaters to residents but maintained and continued to own them even as occupants and owners changed), for instance, installed fewer systems than did the private installers of Davis, but most of their systems are still operating.

Lastly, it seems likely that rapid demographic changes can alter the way local policies are designed, implemented, and perpetuated. Local energy policy may depend on community development to succeed. Special attention must be paid to the needs of new immigrants in order to achieve environmental goals. If solar power or bicycling becomes identified with elite, or "old-timer" culture, rather than with civic engagement, then it runs the risk of being isolated with these ever-decreasing portions of the population.

\section{Resonances within the energy and transportation sectors}

The relationship between community and energy sector issues is getting more attention recently, as the deeply intertwined crises of rising conventional energy costs, food costs, and global warming come more to the fore. In one extreme scenario, that describes the "converging catastrophes of the twenty-first century" as "The Long Emergency" James Howard Kunstler (Kunstler 2005) imagines that communities will have to look inward and organize their local economies for survival as connections to more distant communities are attenuated by expensive travel and the need to produce more food locally. Some community groups are 
embracing the potential for positive change that can grow out of the need to adapt to the limits imposed by energy scarcity and global warming (Hopkins 2008). Regions and communities that have developed on a human scale will be better prepared to survive the long emergency, while living in the vast expanse of suburban and exurban development will be untenable.

One threat to community and civic engagement may be the very infrastructure of suburban life and sprawl that now characterizes life for the majority of Americans (Dreier et al. 2004). As early as 1938, Lewis Mumford called suburbia "a collective effort to lead a private life" (Mumford 1938:412). In his path-breaking history of suburbanization, Kenneth Jackson concluded that "A major casualty of America's drive-in culture is the weakened 'sense of community"' (Jackson 1985:272). The primary way that sprawl threatens civic engagement is that it restricts residents' time. Frumkin et al. (2004:172) noted, "A commuter who arrives home at 6:30 after a grueling fifty-minute commute, feeling tired, depleted, and irritable, is not likely to go back out for a 7:30 meeting of the PTA or the neighborhood association." Additionally, if residents live in Davis but commute to work elsewhere, their commitment and identification with Davis declines in proportion to the amount of time they actually spend in the city.

So what happened to commuting times in Davis over the last decade when cycling declined most precipitously? The percent of commuters whose daily commute was less than fifteen minutes declined from 1990 to 2000 by more than seven percent even though their absolute numbers increased slightly. During that same period, the number of commuters whose commute was between fifteen minutes and half an hour doubled. Commutes longer than an hour increased by 85 percent. Commutes between 30 and 45 minutes increased by 82 percent, and commutes between 45 minutes and an hour increased by 63 percent. If, as Putnam (2000:213) has calculated, each additional 10 minutes of commuting reduces community involvement by 10 percent, then, by my rough calculation, Davis lost between 35 and 40 percent of its potential civic engagement in one decade due solely to increased commute times.

Sprawl can reduce opportunities for spontaneous, informal, social interaction (Oldenburg 1997; Jacobs 1961). Personal experience suggests that people in cars are less likely to stop and schmooze than people on sidewalks and bike paths. Frumkin et al. (2004: Ch. 8) go further, suggesting that driving might actually engender hostility and mistrust, at least for some drivers and under some circumstances. The infrastructure of sprawl and the revealed preferences of those who chose to live there tend to "privatize" social life (Jackson 1985:272). According to one observer, "suburbanites reject the underlying tenets of city life, believing in decentralization, not density, and placing a higher value on the individual than on the community" (Thomas 1998:139). Suburban voters tend to prefer limited government programs, disfavoring anti-discrimination, poverty-reduction (Brauer 2006), and mass transit and congestion reduction programs (Baldassare 1991). In short, sprawl has a right-wing bias. Political conservatives have tended to disfavor renewable energy, although there is some evidence that this is changing at least in California (Baldassare et al. 2008). Thus is it not surprising to see a general coalescence of conservative voting trends, sprawl development, and the defeat of an explicitly "green" development in Davis.

Two recent actions of the Davis City government highlight its diverging engagement with the transportation and building energy efficiency sectors. On one hand, the City renewed its commitment to bicycling with its Bicycle Plan of 2009, which is designed increase bicycle use to at least its peak share of 25 percent. On the other hand, the City, whose pioneering Energy Conserving Building Ordinance was the model for California's energy efficiency building code, Title 24, has finally retired its own building ordinance. The City of Davis Green Building Ordinance was repealed and replaced by the State of California Green Building Standards on the first day of 2011. To be clear, California's building code is among the most advanced in the country, however, Davis's code had historically been designed to exceed the California code. By definition, a house built to code is the most energy-consuming house that one can legally build. By adopting the state energy code, Davis has effectively conceded its leadership position in the area of green building and passive solar development.

These policy choices, hedonic mirror-images of each other, reflect the more general approaches of the City to bicycle transportation and residential energy efficiency. As Davis developed its cultural identity, "Bike City" remained, while the "Solar City" declined in significance. Bike City demanded a renewed commitment to denying the inevitable dominance of the automobile, even as the University's Institute of Transportation Studies gained global prominence for its analysis of various advanced drive-trains, fuels, and future hydrogen fueled economies. Meanwhile "Solar City" faded. There is no solar or Energy Efficient Development Advisory Committee in City government. While the City website has a page for green building, it consists entirely of links to guidance documents generated by external sources. Here, the contrast with the active University academic and research program in energy efficiency is striking as well. The key difference is clear, however: cycling is considered to a legitimate object of collective action and a public good; residential energy efficiency is the concern of the individual homeowner alone. A passive solar neighborhood or development appears to be a concept of the past. 


\section{Broader resonances}

The actors who made Davis a model of bicycle-based transportation and energy efficient housing were pushing against established practices and seeking to buck the trends of increased automobile dominance and sprawling, energy wasteful development. This has parallels in the cases reported in other articles in this Special Section. Phadke reports on the struggle of rural Indian villagers to act as - and be recognized as hydraulic engineering experts (Phadke 2013). Rather than accede to the market monomania, monopsony ${ }^{3}$, and monoculture of the general coffee market, Nicaraguan farming communities found new buyers and new markets that enabled them to value their local culture, cooperative organization, and local ecosystem (Bacon 2013). Rather than accept the property relations and boundaries imposed by distant government agencies, El Salvadorian communities formed in the crucible of war developed their own mapping and governance system based on the actual forest that had grown during the war (de Bremond 2013). In each of these cases the desire for an environmentally benign alternative and the technical capacity to achieve it were necessary, but insufficient.

In each case, it was necessary to develop a coalition of actors and a sense of community identity tied to this alternative path. Thus, the lay hydraulic experts would not have succeeded without the cooperation of the retired government water engineers and the sense of new community identity that was tied to the application of new water rules and new competencies. Without the networks of buyers for values-labeled coffee, the ecologically sustainable growing practices and the more equitable distribution organizations would have failed - unable to compete with the global industrial commodity networks that dominate coffee production and distribution. Likewise, the ethically-labeled coffee buyers would have been unable to bring a sustainable commodity system into being without the existence of a community of coffee growers bound together by a community identity of practice and institutions. In Davis, it was not enough for the Corbetts to conceive of Village Homes and to begin construction. They needed partners on the City council and a community-wide identification with Davis as "an energy conserving city." Bike paths and pleasant weather alone cannot make the bicycle a dominant mode of transportation. The commitment of college presidents, the City council, dedicated bikeways engineers, and a civic identity tied to the bicycle came together to make Davis one of the world's foremost cycling cities.

As with any city anywhere, there are issues of fairness in terms of access to natural resources and exposure to environmental risks in Davis. The environmental harms that the solar and bicycle advocates seek to avoid are extremely diffuse, however. The technologies promoted in Davis are given a moral dimension beyond their characteristics as objects. At a global scale, the effort to reduce greenhouse gas pollution is based on a concern for ecological systems around the world, for human beings in far-off places, and to take responsibility for damage caused by an affluent lifestyle. There is a link between the individual daily choices made by Americans and some of the economic and social injustices in the world. It matters when people in one small city attempt to reduce their consumption of fossil fuels. It matters if they succeed, and it matters if they fail. The importance is not diminished if, at the same time, they try to make their city a more pleasant place to live and to develop a sense of community. In fact, as we have seen, they are unlikely to succeed if they do not.

At a local level, these technologies are expected to provide an infrastructure of conviviality among all members of the community. If, because of a generalized standard for passive solar design including lowincome housing, a greater portion of home heating and cooling is done without fuel costs, this makes living in Davis more affordable for low-income residents. If commuting can be done safely and conveniently by bike and public transit, the effective wages of workers in Davis are higher. However the very attractiveness of Davis is also a threat. Local population growth is outstripping the ability of the city to maintain its sense of community and civic identity. As residential developments eat up more farmland, distances within the city increase, precluding biking for increasing proportions of residents and thus decreasing the support and identification with that part of the Davis way of life. Simultaneously, the new residents bring with them interests, concerns, and identities that are not tied to Davis; and particularly not tied to Davis as an energyconserving city. Soon, the very things that attracted people to the city are destroyed by their influx.

The successes and challenges of Davis as an energy-conserving city validate the emphasis of political ecology on issues of power and discourse and the traditional concern of environmental economics and policy relating to resource crises and ecological limits. It is clear that the participants and actors in Davis were (and continue to be) motivated by a sense of an energy crisis and concern about bumping up against ecological limits. Simultaneously, they found that unless community members were broadly empowered politically, technologically, and socially, they would be unable to make the technological and life-style changes necessary to adapt to the ecological limit confronting them. The environmental conditions of climate and topography made adoption of solar heating, passive solar design, and extensive use of bicycle transportation possible, but clearly (as nearby Woodland attests) not inevitable. Changes in social and political institutions related to outside forces and demography pushed Davis over a threshold where it became increasingly difficult to maintain the technological and social trajectory that put energy conservation at the center of the social and political agenda.

\footnotetext{
${ }^{3}$ A market form in which only one buyer faces many sellers.
} 


\section{Ecologies of Hope}

The dream of a Davis where people went to work, to play, to shop, and to do city business by bike and then returned to convivial, ecologically integrated, passive solar homes was not a dream of revolution. Certainly it was a self-conscious dream of an alternative ideal. It was a reaction against the ever-expanding suburb and car-centered development that had Americans floating through life on a great river of oil. Davisites hoped to be a model of an ecological city to the world, but they were not revolutionaries expecting dominoes to fall in Woodland, Vacaville, Sacramento, and Washington, DC. Instead they were part of a Polanyian double movement that sought to protect their community from the dominant forces of atomization, isolation, and dependency on fossil fuels. As much as they sought to develop and support specific technologies (passive solar design, human powered transport) they had to embed support for these technologies in the cultural, political, and economic institutions of the city. The method then, was not to introduce a revolutionary technology, but to integrate small technologies into the fabric of everyday life, and thus by their cumulative effect make significant change.

\section{References}

Austin, D., and T. Dinan. 2005. Clearing the air: the costs and consequences of higher CAFE standards and increased gasoline taxes. Journal of Environmental Economics and Management 50(3): 562-82.

American Wind Energy Association (AWEA). Federal production tax credit for wind energy. AWEA Website. Online: http://www.awea.org/issues/federal_policy/upload/PTC-Fact-Sheet.pdf [accessed June 2012].

Bacon, C.M. 2013. Quality revolutions, solidarity networks, and sustainability innovations: following Fair Trade coffee from Nicaragua to California. Journal of Political Ecology 20: 98-115.

Balat, M. 2008. Potential importance of hydrogen as a future solution to environmental and transportation problems. International Journal of Hydrogen Energy 33(15): 4013-29.

Baldassare, M. 1991. Transportation in suburbia: trends in attitudes, behaviors and policy preferences in Orange County, California. Transportation 18(3): 207-22.

Baldassare, M., D. Bonner, J. Paluch, and S. Petek. 2008. Californians and the environment. Public Policy Institute of California Website. Online: http://www.ppic.org/content/pubs/survey/S_708MBS.pdf [accessed June 2012].

Barker, J.M. 2005. Is Davis turning red? Sacramento News and Review: 3 Nov.

Beebe, C. and S.M. Wheeler. 2012. Gold Country: the politics of landscape in exurban El Dorado County, California. Journal of Political Ecology 19: 1-16.

Berman, D. M. and J. T. O'Connor. 1996. Who owns the sun? People, politics, and the struggle for a solar economy. White River Junction: Chelsea Green.

Black, J.S., P. Stern and J.T. Elworth. 1985. Personal and contextual influences on household energy adaptations. Journal of Applied Social Psychology 70(1): 3-21.

Bowles, S. and H. Gintis. 2002. Social capital and community governance. The Economic Journal 112(483): 419-436.

Bradsher, K. 2002. High and mighty: SUVs - the world's most dangerous vehicles and how they got that way. New York: Public Affairs.

Brauer, R. 2006. The strange death of liberal America. Westport, Conn: Praeger Publishers.

Brown, L.R. 2006. Plan B 2.0: rescuing a planet under stress and a civilization in trouble. New York: W.W. Norton \& Co.

Buehler, T.J. 2007. Fifty years of bicycle policy in Davis, CA. Masters dissertation. Davis, CA: Institute for Transportation Studies, University of California. Presentation here

Bustos, T. 2005. Bicycle Coordinator, City of Davis. Personal Interview.

Calthorpe, P., M.N. Corbett, A. Duany, E. Moule, E. Plater-Zyberk and S. Polyzoides. 1991. Ahwahnee principles for resource-efficient communities. Local Government Commission Website. [accessed December 12 2008] http://www.lgc.org/ahwahnee/ahwahnee_principles.pdf

Carlson, R. C., S. J. Everett, W. W. Harman, K. W. Krause, S. Levy, T.F. Mendel, P. C. Meagher, L. Rosener, P. Schwartz and T. C. Thomas. 1980. California energy futures: Two alternative societal scenarios and their energy implications. Technological Forecasting and Social Change 18(4): 321339.

Cheney, R. 2001. Speech on energy policy at the Energy Efficiency Forum. Associated Press.

City of Davis. 2012. Municipal code: Buildings, energy conservation standards for alternations and remodels that increase the glazing and not the conditioned floor area, findings. Ch. 8, Article 2 §.010(g). Quality Code Publishing Website. [accessed April 1 2012] http://qcode.us/codes/davis/

City of Davis. 2009. City of Davis Bicycle Plan. City of Davis Website. [accessed November 262011 ] http://cityofdavis.org/bicycles/pdfs/Bike-Plan-2009.pdf 
Corbett, J. and M.N. Corbett. 2000. Designing sustainable communities: learning from village homes. Washington D.C: Island Press.

Corson, W. H. 2002. Recognizing hidden environmental and social costs and reducing ecological and societal damage through tax, price, and subsidy reform. The Environmentalist 22: 67-82.

De Young, R. 1993. Changing behavior and making it stick: the conceptualization and management of conservation behavior. Environment and Behavior 25(3): 485-505.

De Bremond, A. 2013. Regenerating conflicted landscapes in post-war El Salvador: livelihoods, land policy, and land use change in the Cinquera Forest. Journal of Political Ecology 20: 116-136.

DeLeuw, Cather \& Co. 1972. Bicycle circulation and safety study for the City of Davis. University of California, Davis.

Dietz, T. and E. L. Vine. 1982. Energy impacts of a municipal conservation policy. Energy 7(9): 755-758.

Dreier, P., J.H. Mollenkopf and T. Swanstrom. 2004. Place matters: metropolitics for the twenty-first century. Lawrence: University Press of Kansas.

Energy Information Administration (EIA). 1998. Annual Energy Review 1997. Washington D.C.: DOE/EIA0384(97).

Energy Information Administration (EIA). 2011. Annual Energy Outlook. Washington D.C.: EIA.

Fitch, M. Growing pains: thirty years in the history of Davis. City of Davis Website. [accessed Novermber 26 2008] http://cityofdavis.org/cdd/cultural/30years/about.cfm

Francis, M. 2003. Village homes: a community by design. Washington D.C.: Island Press.

Francis, M. 2005. Informal greenways tour. Paper presented at the Davis Greenways Tour. Davis, California.

Friedman, T.L. 2008. Hot, flat, and crowded: why we need a green revolution - and how it can renew America. New York: Farrar, Straus and Giroux.

Frumkin, H., L.D. Frank and R. Jackson. 2004. Urban sprawl and public health: designing, planning, and building for healthy communities. Washington D.C.: Island Press.

Gamson, W.A. and A. Modigliani. 1989. Media discourse and public-opinion on nuclear-power - a constructionist approach. American Journal of Sociology 95(1): 1-37.

Gardner, G.T. and P.C. Stern. 2002. Environmental problems and human behavior. Boston: Pearson Custom Pub.

Geller, H.S. 2003. Energy revolution: policies for a sustainable future. Washington D.C.: Island Press.

Georg, S. 1999. The social shaping of household consumption. Ecological Economics 28(3): 455-466.

Goulder, L.H. and B.M. Nadreau. 2002. International approaches to reducing greenhouse gas emissions. In S. H. Schneider, A. Rosencranz, and J.O. Niles (eds.) Climate change policy: a survey. Washington D.C.: Island Press. Pp 115-150.

Grafton, R.Q., T. Kompas and N. Van Long. 2010. Biofuels subsidies and the green paradox. Center for Economic Studies \& IFO Institute for Economic Research (CESifo) Working Paper 2960.

Granovetter, M. 1985. Economic action and social structure: the problem of embeddedness. The American Journal of Sociology 91(3): 481-510.

Greening, L.A., D.L. Greene, and C. Difiglio. 2000. Energy efficiency and consumption-the rebound effect-a survey. Energy Policy 28(6): 389-401.

Gregory, D.P., D.Y.C. Ng, and G.M. Long. 1973. The hydrogen economy. Scientific American 228(1): 1321.

Hackett, B. and L. Lutzenhiser. 1991. Social structures and economic conduct: interpreting variations in household energy consumption. Sociological Forum 6(3): 449-470.

Hammond, J. 1974. A strategy for energy conservation: proposed energy conservation and solar utilization ordinance for the City of Davis, California. Davis: City of Davis.

Hammond, J. 1980. Senda Nueva project description. Archives of California: Energy Commission, SolarCal Council, Project Files: S, F 3912:210.

Hammond, J., J. Zanetto and C. Adams. 1981. Plannina solar neighborhoods. Sacramento: California Energy Resources Conservation and Development Commission.

Hamrin, J. 1978. Two energy conserving communities: implications for public policy. Ph.D. Dissertation. Davis, USA: University of California, Davis.

Harris, R. 2005. Cows, not Covellians, worry us. The Davis Enterprise. http://www.davisenterprise.com

Hawken, P., A.B. Lovins and L. H. Lovins. 1999. Natural capitalism: creating the next industrial revolution. London: Earthscan.

Headey, D. and S. Fan. 2008. Anatomy of a crisis: the causes and consequences of surging food prices. Agricultural Economics 39 (Suppl.s1): 375-391.

Hess, D.J. 2005. Technology- and product-oriented movements: approximating social movement studies and science and technology studies. Science Technology Human Values 30(4): 515-535. 
Hess, D.J. 2006. Democracy, sustainable consumption, and the problem of scale. Paper presented at the Conference on Sustainable Consumption, June 2006, Madison.

Hopkins, R. 2008. The transition handbook: from oil dependency to local resilience. Totnes: Green Books. IEA. 1998. World Energy Outlook. Paris: IEA Publications.

Jackson, K.T. 1985. Crabgrass frontier: the suburbanization of the United States. Oxford: Oxford University Press.

Jacobs, J. 1961. The death and life of great American cities. New York: Random House.

Jacobsons, J. and J. Corbett. 1978. Davis, an energy conserving city: a self guided tour. Davis: University of California Energy Extension Service.

Jones, S. 1989. The Davis greenway: a conceptual plan for open space and wildlife habitat for the City of Davis. Davis: UC Davis Center for Design Research.

Kammen, D.M. and R.M. Margolis. 2002. Energy R\&D and innovation: challenges and opportunities. In S. H. Schneider, A. Rosencranz and J.O. Niles (eds.) Climate change policy: a survey. Washington D.C.: Island Press. Pp 469.

Kunstler, J.H. 2005. The long emergency: surviving the converging catastrophes of the twenty-first century. New York: Atlantic Monthly Press.

Kutscher, C.F. 2007. Tackling climate change in the U.S.: potential U.S. carbon emissions reductions from renewable energy and energy efficiency by 2030. American Solar Energy Society.

Landis, B., V. Vattikuti, R. Ottenberg, T. Petritsch, M. Guttenplan and L. Crider. 2003. Intersection level of service for the bicycle through movement. Transportation Research Record: Journal of the Transportation Research Board 1828(1): 101-106.

Larkey, J.L. 1969. Davisville '68: The history and heritage of the City of Davis, Yolo County, California. In Commemoration of the 100th anniversary of the founding of Davisville in 1868. Davis: Davis Historical and Landmarks Commission.

League of American Bicyclists. 2005. First platinum-level bicycle friendly community recognized. Press Release. League of American Bicyclists Website. [accessed October 21 2006] http://www.bicyclefriendlycommunity.org/October2005award.htm

Lenz, T. 1990. A post-occupancy evaluation of village homes, Davis, California. Ph.D. Dissertation. Munich, Germany: Technical University of Munich.

Leonard-Barton, D. 1981. Voluntary simplicity lifestyles and energy conservation. The Journal of Consumer Research 8(3): 243-252.

Lofland, J. 2004. Davis: radical changes, deep constants. Charleston: Arcadia.

Loux, J. and R. Wolcott. 1994. Innovation in community design: the Davis experience. Davis: City of Davis.

Lovins, A.B. and L.H. Lovins. 1982. Brittle power: energy strategy for national security. Andover: Brick House Pub. Co.

MacKay, D.J.C. 2008. Sustainable energy — without the hot air. Cambridge: UIT Press.

Mathews, J.A. 2008. How carbon credits could drive the emergence of renewable energies. Energy Policy 36(10): 3633-3639.

McDowall, W. and M.Eames. 2006. Forecasts, scenarios, visions, backcasts and roadmaps to the hydrogen economy: a review of the hydrogen futures literature. Energy Policy 34(11): 1236-1250.

McPherson, B. 2006. Secretary of State Bruce Mcpherson releases 60-day report of registration. News Release BM06:053. Sacramento: California Secretary of State.

Mitchell, A. and C. MacNulty. 1981. Changing values and lifestyles. Long Range Planning 14(2): 37-41.

Mumford, L. 1938. The culture of cities. New York: Harcourt, Brace.

Myers, N. and J. Kent. 2001. Perverse subsidies: how tax dollars can undercut the environment and the economy. Washington D.C.: Island Press.

New Urbanism 2009. Principles of urbanism. New Urbanism Website. [accessed October 20 2009] http://www.newurbanism.org/newurbanism/principles.html

Niemeier, D., G. Gould, A. Karner, M. Hixson, B. Bachmann, C. Okma, Z. Lang and D. Del Valle Heres. 2008. Rethinking downstream regulation: California's opportunity to engage households in reducing greenhouse gases. Energy Policy 36(9): 3436-3447.

Oldenburg, R. 1997. The great good place: cafés, coffee shops, community centers, beauty parlors, general stores, bars, hangouts, and how they get you through the day. New York: Marlowe \& Co.

Olsen, M.E. 1983. Public acceptance of consumer energy conservation strategies. Journal of Economic Psychology 4(1-2): 183-196.

Pacala, S. and R. Socolow. 2004. Stabilization wedges: solving the climate problem for the next 50 years with current technologies. Science 305(5686): 968-972. 
Palmer, K. and D. Burtraw. 2005. Cost-effectiveness of renewable electricity policies. Energy Economics 27(6): 873-894.

Parker, C. B. 2003. Campus's love of bicycles keeps rolling along; but growing pains challenge traditional mode of travel. UC Davis Dateline Website. [accessed December 22 2012] http://www.dateline.ucdavis.edu/dl_detail.lasso?id=6494

Perrow, C. 1999. Normal accidents: living with high-risk technologies. Princeton: Princeton University Press. Phadke, R. 2013. Water works in India. Journal of Political Ecology 20: 80-97.

Pigou, A.C. 1920. The economics of welfare. London: Macmillan.

Poortinga, W., L. Steg, C. Vlek and G. Wiersma. 2003. Household preferences for energy-saving measures: a conjoint analysis. Journal of Economic Psychology 24(1): 49-64.

Portney, K. E. 2003. Taking sustainable cities seriously: economic development, the environment, and quality of life in American cities. Cambridge, Mass: MIT Press.

Portney, K. E. 2005. Civic engagement and sustainable cities in the United States. Public Administration Review 65(5): 579-591.

Proops, J. 2001. The (non-) economics of the nuclear fuel cycle: an historical and discourse analysis. Ecological Economics 39(1): 13-19.

Putnam, R. D. 2000. Bowling alone: the collapse and revival of American community. New York: Simon and Schuster.

Rader, N.A. and R. B. Norgaard. 1996. Efficiency and sustainability in restructured electricity markets: the renewables portfolio standard. The Electricity Journal 9(6): 37-49.

Rajan S.R. and C.A.M. Duncan. 2013. Ecologies of Hope: environment, technology and habitation - case studies from the intervenient middle. Journal of Political Ecology 20: 70-79.

Rifkin, J. 2003. The hydrogen economy: the creation of the worldwide energy web and the redistribution of power on earth. New York: Penguin Group.

Rosenthal, E. 2008. Europe, cutting biofuel subsidies, redirects aid to stress greenest options. New York Times. 22 Jan.

Rubin, O.D., M. Carriquiry and D.J. Hayes. 2008. Implied objectives of US biofuel subsidies. Working Paper 1-31. Center for Agricultural and Rural Development.

Sclove, R. 1995. Democracy and technology. New York: Guilford Press.

Sommers, R. 2003. Where have all the cyclists gone? Davis Enterprise: May 18.

Sorrell, S., J. Dimitropoulos and M. Sommerville. 2009. Empirical estimates of the direct rebound effect: a review. Energy Policy 37(4): 1356-1371.

Sperling, D. and J.S. Cannon (eds.). 2007. Driving climate change: cutting carbon from transportation. Academic Press.

Sperling, D. and N. Lutsev. 2009. Energy efficiency in passenger transportation. The Bridge. National Academy of Engineering. 39 (2): 22-30.

Springer, D. 1998. Comment. Davis Community Network Website. [accessed May 1 2007] http://www.dcn.davis.ca.us/discus/messages/42/43.html?ThursdayDecember319980632pm

Stello, S. 2006. Housing co-op turning 20. The Davis Enterprise: February 27.

Stern, P. 1992. What psychology knows about energy conservation. American Psychologist 47(10): 12241232.

Stone, D. A. 2002. Policy paradox: the art of political decision making. New York: Norton.

Thayer, R. L. 2000. Forward. In J. Corbett and M.N. Corbett (eds.) Designing sustainable communities: learning from village homes. Washington D.C: Island Press. Pp. Xv.

Thomas, G. S. 1998. The United States of suburbia: how the suburbs took control of America and what they plan to do with it. Amherst: Prometheus.

Trostle, R. 2008. Global agricultural supply and demand: Factors contributing to the recent increase in food commodity prices. Outlook Report No. WRS-0801. USDA Economic Research Service.

U.S. Census Bureau. 1980. Census of population, 1980, special Seedis file: Census of population and housing, summary tape file 3. Oakland: California Digital Library. [accessed October 15 2006]

U.S. Census Bureau .1990. Census of population, 1990, special Seedis file: Census of population and housing, summary tape file 3. Oakland: California Digital Library. [accessed October 15 2006]

U.S. Census Bureau. 2000. Census of Population, 2000, special Seedis file: Census of Population and housing, summary tape file 3. Oakland: California Digital Library. [accessed October 15 2006]

U.S. Census Bureau. 2010a. Profile of general population and housing characteristics: 2010, table Dp-1. 2010 Census. U.S. Census Bureau American Fact Finder Website. [accessed Nov 26 2011] http://factfinder2.census.gov/faces/nav/jsf/pages/index.xhtml 
U.S. Census Bureau. 2010b. 2008-2010 American community survey, Table B25040, house heating fuel. American Community Survey. U.S. Census Bureau American Fact Finder Website. [accessed Nov 26 2011] http://factfinder2.census.gov/faces/nav/jsf/pages/index.xhtml

U.S. Census Bureau. 2010c. Table S0801, commuting characteristics by sex. 2008-2010 American community survey 3-Year estimates. U.S. Census Bureau American Fact Finder Website. [accessed Nov 26 2011] http://factfinder2.census.gov/faces/nav/jsf/pages/index.xhtml

Veblen, T. 1998. The theory of the leisure class. Amherst: Prometheus Books.

Veblen, T. 2006. Conspicuous consumption. New York: Penguin Books.

Von Blottnitz, H. and M.A. Curran. 2007. A review of assessments conducted on bio-ethanol as a transportation fuel from a eet Energy, greenhouse gas, and environmental life cycle perspective. Journal of Cleaner Production 15(7): 607-619.

Winner, L. 1977. Autonomous technology: technics-out-of-control as a theme in political thought. Cambridge: MIT Press.

Winner, L. 1992. Democracy in a technological society. Dordrecht: Kluwer. 


\begin{abstract}
Solutions to the climate and energy crises will likely involve large scale renewable energy technology deployment and of renewable energy technologies in building energy systems and transportation systems. But they will also require changes in lifestyle, behavior, and social organization. Solar heating and bicycle use are well-developed technologies that exemplify social-technological hybrids. Davis, California, has established a national reputation as a bike-friendly city and has been an international leader in supporting energy efficient housing developments. Support, however, has waxed and waned over the years. Davis provides an ideal case study to explore the conditions necessary to develop a sustained community commitment to passive solar design and human powered transport at a scale large enough to make a difference. This analysis points to the importance of local politics, municipal identity tied to an energy or environmental vision, and the organization of social capital to influence broad-based technological choice.
\end{abstract}

Key words: solar heating, bicycle lanes, social capital, behavior, environmental politics.

\title{
Resume
}

Les solutions aux problèmes d'énergie et de réchauffement climatique incluront très probablement un déploiement à grande échelle de technologie pour les énergies renouvelables dans la construction de systèmes énergétiques et de transport, mais elles exigeront également un changement de mode de vie, de comportement, et d'organisation sociale. Le chauffage solaire et l'utilisation de bicyclettes sont des technologies très au point, et qui constituent un exemple d'hybrides socio-technologiques. La ville de Davis en Californie s'est bâti une réputation de cité pro-cyclistes, et elle est un des leaders internationaux dans le développement de logements à basse consommation d'énergie. Toutefois, ce soutien est en déclin depuis plusieurs années. Davis constitue une étude de cas idéale pour explorer les conditions nécessaires au développement d'un attachement communautaire longue-durée à la promotion de l'ingénierie solaire passive, ainsi qu'aux moyens de locomotion propulsés par l'homme, à une échelle assez grande pour changer les choses. Cette analyse montre l'importance de la politique locale, celle d'une identité communale liée à une vision énergétique et environnementale, et celle de l'organisation du capital social pour influencer un choix général en termes de technologie.

Mots-clés: chauffage solaire, pistes cyclables, le capital social, le comportement humain, la politique de l'environnement.

\section{Resumen}

Las soluciones para las crisis climáticas y energéticas probablemente implicarán la utilización de tecnologías de energía renovable a gran escala para construir sistemas de energía y de transporte, pero también exigirán cambios en el estilo de vida, el comportamiento y la organización social. La calefacción solar y el uso de bicicletas son tecnologías bien desarrolladas que ejemplifican los híbridos socio-tecnológicos. La ciudad de Davis, California, ha conseguido reputación nacional como ciudad perfectamente adaptada al uso de bicicletas y ha sido líder internacional en el apoyo de planeamientos urbanos energéticamente eficientes. Sin embargo, el apoyo ha tenido altibajos a través de los años. Davis constituye un caso práctico ideal para analizar las condiciones necesarias para desarrollar un compromiso comunitario continuo con el diseño solar pasivo y el transporte de tracción humana a una escala suficientemente grande para marcar una diferencia. Este análisis señala la importancia de la política local, la identidad municipal ligada a una visión energética o medioambiental y la organización de capital social para influenciar una elección tecnológica amplia.

Palabras clave: calefacción solar, carriles para bicicletas, el capital social, el comportamiento, la política ambiental. 